JAR,Volume 4 Nomor 1 April 2021

p-ISSN 2615-417X, e-ISSN 2721-0782

DOI : https://doi.org/10.47647/jar

\title{
ANALISIS KELAYAKAN TEKNIS DAN FINANSIAL USAHA AIR MINUM DENGAN SISTEM STERILISASI PEREBUSAN (Studi Kasus Di Depot Kang Santri Gampong Rhieng Blang Kecamatan Meureudu Pidie Jaya)
}

\author{
Al-Asri Abubakar ${ }^{(1)}$, Hamdani ${ }^{(2)}$, Aditya Saputra ${ }^{(2)}$ \\ Program Studi Agribisnis Fakultas Pertanian Universitas Jabal Ghafur glee gapui -sigli \\ Email : Putraputra18826@gmail.com
}

\begin{abstract}
ABSTRAK
Depot air masak merupakan industri yang melakukan proses pengolahan air mentah menjadi air masak yang dikemas kegalon, dan dijual langsung kepada konsumen untuk mengetahui kelayakan finansial usaha air masak dengan sistem sterelisasi perebusan (Studi Kasus Di Depot Kang Santri Gampong Rhieng Blang Kecamatan Meureudu Pidie Jaya). Objek penelitian ini adalah di depot Kang Santri Gampong Rhieng Blang Kecamatan Meureudu Kabupaten Pidie Jaya. Penelitian ini adalah penelitian deskriptif analisis dengan menggunakana pendekatan analisis pendekatan kualitatif dan kuantitatif dengan jumlah sampel yang diambil 5 orang. Berdasarkan kelayakan finansial usaha air masak dengan sistem sterilisasi perebusan di depot Kang Santri Gampong Rhieng Blang Kecamatan Meureudu Kabupaten Pidie Jaya memiliki rata-rata biaya produksi RP. 7.972.500 yang terdiri dari rata-rata penerimaan sebesar Rp. 10.192.000/bulan bersih pendapatan dan rata-rata pendapatan usaha Rp. 2.219500/bulan dari pendapatan bersih. Nilai R/Ratio 1,28 memberikan arti bahwa dengan modal Rp. 1 menghasilkan pendapatan sebesar 1,28 hal ini menunjukan usaha air masak Kang Santri layak untuk di usahakan.
\end{abstract}

Kata kunci: Pendapatan, Kelayakan, Finansial, Air Masak

\section{PENDAHULUAN}

Latar Belakang Masalah

Setiap usaha dalam menjalankan usaha bisnis nya, tidak akan terlepas dari berbagai kendala baik itu dari pembelajaran produksi, pemasaran maupun personalia di samping itu usaha juga menghadapi persaingan yang ketat dengan usaha-usaha yang lain. Halim, Abdul (2005).

Seiring dengan berkembangnya teknologi dan semakin menigkatnya minat konsumen terhadap air masak yang siap untuk dikonsumsi, dewasa ini telah berkembang usaha baru di bidang air masak yang dihasilkan oleh depot air masak.

Depot air masak merupakan industri yang melakukan proses pengelohan air baku menjadi air masak yang diisikan ke galon dan dijual langsung kepada konsumen.

Investasi sangat penting dilakukan oleh suatu usaha guna menjaga persaingan jangka panjang. Investasi suatu proyek harus didahului oleh kajian untuk menganalisis kelayakan secara menyeluruh serta mendapatkan informasi yang berhubungan denga resiko yang di hadapi. (Husnan, S.et.al 
JAR,Volume 4 Nomor 1 April 2021

p-ISSN 2615-417X, e-ISSN 2721-0782

DOI : https://doi.org/10.47647/jar

2000). Hasil dari kajian kelayakan bisnis akan menjadi acuan bagi pengambilan keputusan bahwa suatu usaha layak dikerjakan atau sebaliknya.

Analisis kelayakan bisnis merupakan input bagi investor untuk memprediksi kondisi dan resiko yang akan dihadapi dari bisnis yang akan dijalankan atau sudah berjalan. Cahyani (2014) menyatakan bahwa sterilisasi merupakan suatu cara untuk mematikan dan menghilangkan semua organisme yagn terdapat pada satu benda.

\section{Batasan Masalah}

Batasan masalah yang terdapat dalam penulisan ini adalah studi kelayakan yang ditinjau dari aspek finansial.

\section{Rumusan Masalah}

Berdasarkan latar belakang terdapat permasalahan dalam penelitian adalah bagaimana kelayakan usaha dan teknis finansial di depot Kang Santri Gampong Rhieng Blang Kecamatan Meureudu Kabupaten Pidie Jaya.

\section{Tujuan}

Untuk mengetahui layak tidak nya usaha air masak dengan sistem sterilisasi perebusan studi kasus di depot Kang Santri, serta untuk mengetahui teknis finansial di depot tersebut.

\section{Asumsi}

Asumsi penulis dalam penelitian ini adalah usaha air masak dengan sistem sterilisasi perebusan di depot Kang Santri di duga layak dari segi teknis dan finansial.

\section{Metode}

\section{Lokasi, Waktu, Objek Dan Ruang Lingkung Peneltian}

Penelitian ini dilakukan di depot Kang Santri Gampong Rhieng Blang Kecamatan Meureudu Kabupaten Pidie Jaya, penelitian dimulai pada bulan November 2019 yang merupakan bisnis yang bergerak di bidang air masak.

\section{Jenis Dan Pendekatan Penelitian}

Penelitian ini merupakan penelitian deskriptif analisis dengan menggunakan pendekatan kualitatif dan kuantitatif. Metode deskriptif adalah suatu metode yang bertujuan untuk mendeskripsikan kejadian yang terjadi pada saat sekarang. (Sudjana, 2001).

Sedangkan pendekatan kualitatif adalah penelitian yang bermaksud untuk memahami fenomena tentang apa yang dialami subjek penelitian (Moleong, 2012).

Pendekatan kuantitatif adalah penelitian yang menggunakan metode bilangan suatu objek atua variabel menjadi bagian pengukuran. (Izaak Latanusa, 2004)

\section{Populasi Dan Sample \\ Populasi}

Tidak ada populasi dalam penelitian karena objek sasaran satu lokasi penelitian sehingga tidak ditentunkan jumlah populasi Sampel

Jumlah sampel yang di ambil dalam penelitian ini adalah 5 orang meliputi pemilik usaha dan karyawan pada usaha tersebut.

\section{Jenis Dan Sumber Data}

Menurut faisal (2018) data primer adalah data yang dikumpulkan langsung oleh peneliti untuk pertama kalinya melalui usaha di lapangan mencakup Survei, Observasi, Pengujian Fisik, Pengiriman Email Kepada Responden, Mengisi Kuesioner, Wawancara, Dan Studi Kasus sedangkan data sekunder data yang dikumpulkan dari instansi, lembaga atau orang lain. 
JAR,Volume 4 Nomor 1 April 2021

p-ISSN 2615-417X, e-ISSN 2721-0782

DOI : https://doi.org/10.47647/jar

\section{Metode Analisis}

Menurut sugiyono (2008) analis data adalah proses mencari dan menyusun secaras sistematis data yang diperoleh dari hasil wawsancara, catatan lapangan dan bahanbahan lain sehingga mudah dipahami dan temuannya dapat di informasikan kepada orang lain.

Dalam penelitian ini penulis menggunakan analisis data secara deskriptif dan kulitatif.

Analisis Biaya

Menurut (noor 2007) analisis biaya adalah semua pengeluaran dalam bentuk dana untuk memperoleh faktor-faktor produksi yang akan digunakan untuk menghasilkan barang-barang produksi oelh usaha.

Rumus analisis biaya

$\mathrm{TC}=\mathrm{TVC}+\mathrm{TFC}$

Dimana :

$\mathrm{TC}=$ Total Biaya $(\mathrm{Rp})$

TVC = Total Biaya Variabel $(\mathrm{Rp})$

TFC = Total Biaya Tetap $(\mathrm{Rp})$

Pendapatan dihitung melalui pengurangan antara penerimaan dengan total biaya.

Rumus Pendapatan :

TR $=$ P.Q

Dimana :

$\mathrm{TR}=$ Penerimaan Total $(\mathrm{Rp})$

$\mathrm{P} \quad=$ Harga $(\mathrm{Rp} /$ Buah $)$

Q = Jumlah Produksi (Rp/Bulan)

Keuntungan di hitung melalui pengurangan total penerimaan dengan total biaya

Rumus Pengurangan

$\mathrm{II}=\mathrm{TR}-\mathrm{TC}$
Dimana :

II $=$ Total Keuntungan $(\mathrm{Rp})$

$\mathrm{TR}=$ Total Penerimaan $(\mathrm{Rp})$

$\mathrm{TC}=$ Total Biaya $(\mathrm{Rp})$

2.5.2 Benefit Cost Ratio (B/C Ratio)

B/C Ratio merupakan perbandingan antara penerimaan total dan biaya total.

$$
\mathrm{BC}=\frac{T K}{T C}
$$

Dimana :

$\operatorname{Tr}=$ Total Penerimaan

$\mathrm{TC}=$ Total biaya

2.5.3 Return of invesment (ROI)

ROI $\frac{\text { Keutungan Usaha }}{\text { Modal Usaha }} \times 100 \%$

Kriteria :

Apabila ROI > 1, maka Usaha deoot usaha air masak layak dijalankan

Apabila ROI <1, maka Usaha depot usaha air masak tidak layak dijalankan.

HASIL DAN PEMBAHASAN

Hasil Penjualan

\begin{tabular}{|l|l|}
\hline \multicolumn{1}{|c|}{ Bulan } & \multicolumn{1}{c|}{$\begin{array}{c}\text { Hasil penjualan per } \\
\text { bulan }\end{array}$} \\
\hline Januari & Rp9.822.000 \\
Februari & Rp10.272.000 \\
Maret & Rp10.482.000 \\
& \\
\hline
\end{tabular}

Berdasarkan tabel diatas untuk bulan Januari Rp9.822.000, yang penjualan usaha kang santri. Untuk bulan februari Rp10.272.000, yang penjualan usaha kang santri. Untuk bulan maret adalah Rp10.482.000. 
JAR,Volume 4 Nomor 1 April 2021

p-ISSN 2615-417X, e-ISSN 2721-0782

DOI : https://doi.org/10.47647/jar

Rata-rata hasil penjualan

\begin{tabular}{|l|l|}
\hline \multirow{2}{*}{ Bulan } & $\begin{array}{l}\text { Hasil penjualan Galon/jirigen } \\
\text { RO\&Air Masak rata-rata } \\
\text { perhari }\end{array}$ \\
\hline Januari & 55/Unit \\
Februari & 57/Unit \\
Maret & 58/Unit \\
\hline
\end{tabular}

Berdasarkan tabel diatas hasil penjualan galon air perhari dari usaha Kang Santri pada bulan Januari adalah 55/unit, untuk penjualan bulan Februari adalah 57/unit, untuk bulan Maret adalah 58/unit (data hasil terlampir)

\begin{tabular}{|l|l|}
\hline Bulan & $\begin{array}{l}\text { Hasil penjualan rata-rata } \\
\text { perhari }\end{array}$ \\
\hline Januari & Rp327.400 \\
Februari & Rp342.400 \\
Maret & Rp349.400 \\
\hline
\end{tabular}

Berdasarkan tabel diatas hasil penjualan usaha kang santri pada bulan Januari adalah Rp327.400, yang penjualan pada bulan Februari adalah Rp342.400, yang pada bulan bulan Maret adalah Rp349.400.

\section{Biaya Produksi}

Berdasarkan hasil penelitian biaya yang dikeluarkan oleh usaha air masak Kang Santri Di Gampong Rhieng Kecamatan Meureudu Kabupaten Pidie Jaya biaya tetap air masak Rp.4.970.000 sedangkan biaya variabel RP3.002.500, dengan jumlah rata-rata biaya Rp.7.972.00

\section{Pendapatan}

\begin{tabular}{|l|l|}
\hline Uraian & $\begin{array}{l}\text { Jumlah } \\
\text { Pendapatan }\end{array}$ \\
\hline Rata-rata penerimaan & Rp10.192.000 \\
Total Biaya Produksi & Rp7.972.500 \\
Rata-Rata & Rp.2.219.500 \\
Pendapatan/Bulan & \\
\hline
\end{tabular}

Berdasarkan tabel diatas dapat diketahui bahwa rata-rata biaya produksi $\mathrm{Rp}$ Rp7.972.500 yang terdiri dari rata-rata penerimaan Rp10.192.000/bulan dari bersih pendapatan dan rata-rata pendapatan sebesar Rp.2.219.500/bulan dari pendapatan bersih.

\section{Benefit Cost Ratio (Bc/ Ratio)}

Nilai R/C Ratio :

R/C Ratio $\frac{10.192 .00}{7.972 .500}$

$$
=1.28
$$

Nilai B/C Ratio 1,28 memberikan arti bahwa dengan modal Rp.1 menghasilkan pendapatan 1.28.

\section{Return Of investmen}

Return Of investmen dapat di hitung dengan cara :

$$
\begin{aligned}
\text { ROI } & =\frac{10.192 .000}{25.000 .000} \times 100 \% \\
& =40,8
\end{aligned}
$$

Dari perhitungan Return Of investmen Usaha air masak Kang Santri Di Gampong Rhieng Blang Kecamatan Meureudu Kabupaten Pidie Jaya memiliki nilai ROI $>1$.

Tahapan produksi air masak kang santri

Dalam memproduksi air masak depot kang Santri Memiliki beberapa tahapan :

1. Persiapan alat dan bahan produksi, meliputi air, panci perebusan, kayu bakar, tutup galon, bahan sterilisasi, tisu pembersih, segel galon.

2. Pengolahana bahan baku produksi menjadi produk air masak siap konsumsi.

\section{Teknis produksi air masak Kang Santri}

Adapun teknis sebagai berikut :

1. Menyediakan alat dan bahan produksi. 
JAR,Volume 4 Nomor 1 April 2021

p-ISSN 2615-417X, e-ISSN 2721-0782

DOI : https://doi.org/10.47647/jar

2. Melakukan penyucian terhadap wadah perebusan.

3. Melakukan penyucian tahap kedua menggunakan bahan sterilisasi, hal ini dilakukan dengan tujuan untuk membunuh bakteri.

4. Memindahkan wadah perebusan kearea perebusan.

5. Lalu pihak depot melakukan pengisian air mentah kedalam wadah perebusan.

6. Selanjutnya pihak depot Kang Santri melakukan penyalaan api untuk merebus air tersebut.

7. Setelah air mendidih pihak depoit kang santri melakukan pendinginan terlebih dahulu, kemudian baru dipindahkan ke wadah penampungan air masak siap konsumsi.

8. Air siap dipasarkan kepada konsumen.

\section{KESIMPULAN}

Bedasarkan hasil pembahasan bahwa usaha depot Kang Santri layak untuk dijalankan dari segi teknis maupun finansial nya.

\section{UCAPAN TERIMAKASIH}

Penulis mengucapkan kepada semua pihak yang telah membimbing dalam menyelesaikan penyusunan jurnal ini

\section{DAFTAR PUSTAKA}

Eprints.ums.ac.id

Halim, Abdul.2003. Analisis Investasi. Edisi Pertama. Salembab Empat. Jakarta

Husnan, S. dan Suwarsono, M. 2000. Studi Kelayakan Proyek, Edisi ke-4, Unit Penerbit dan Percetakan, Yogyakarta

Noor, 2007. Ekonomi Manajerial. PT. Raja Grafindo Persada, Jakarta

Sudjana, 2001 Metode Statistika, Edisi Revisi, Bandung : Tarsito

Faisal, 2018 Sterilisasi dan Macam Macamnya, Lembaga teknik. Rineke Cipta. Jakarta.

Sugiyono.2008. Metode Penelitian Kauntitatif Kualitatif dan $R \& D$. Bandung: ALFABETA 